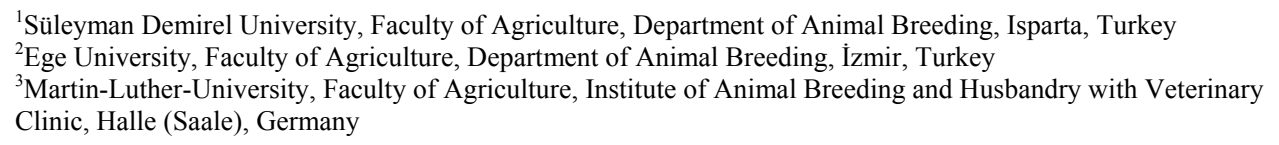

ERGUL IŞGUZAR ${ }^{1}$, CETIN KOCAK $^{2}$ and HEINZ PINGEL ${ }^{3}$

\title{
Growth, carcass traits and meat quality of different local ducks and Turkish Pekins (short communication)
}

\begin{abstract}
Summary
The purpose of the research was to study growth, carcass traits and meat quality of Kara, Yesilbas and Boz ducks (as the local names), in comparison with Turkish Pekin ducks in Isparta province, Turkey.

Average body weights of Kara, Yesilbas, Boz and Turkish Pekin ducks were 42.3, 44.5, 48.0 and 46.2g for dayold ducklings; 1036.5, 1154.5, 1115.3 and 1168.7g for 4 weeks old ducklings; 1660.7, 1824.7, 1894.0 and 1744.2g for 8-week old ducks; 1816.0, 1999.0, 2044.0 and 1885.5g for 12-week old ducks, respectively. Average percentages of slaughter yield were $71.5,72.5,73.7$ and $71.3 \%$. The percentages of breast and leg meat to the carcass were $34.34,34.1,33.8,36.7 \%$, respectively.

Average percentages of crude protein content for breast and leg meat were 20.2, 20.0, 20.3, 20.7\% and 20.1, $19.4,18.8,19.4 \%$, respectively. The content of crude fat for breast and leg meat were $10.3,5.8,8.3,14.9 \%$ and $10.6,6.4,8.9,15.1 \%$ respectively. Because of the lower fat percentage, the local duck breeds could be important for a commercial crossbred program.
\end{abstract}

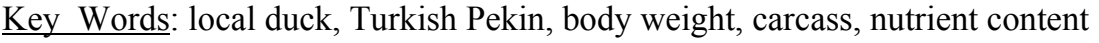

\section{Zusammenfassung}

Titel der Arbeit: Wachstum, Schlachtkörperzusammensetzung und Fleischqualität verschiedener lokaler Entenrassen und Türkischer Pekingenten (Kurzmitteilung)

Das Ziel der Arbeit bestand darin, das Wachstum, die Schlachtkörperzusammensetzung und die Fleischqualität der lokalen Entenrassen Kara, Yesilbas und Boz mit Türkischen Pekingenten zu vergleichen. Die Körpergewichte der Kara-, Yesilbas-, Boz- und Pekingenten betrugen im Eintagsalter 42,3, 44,5, 48,0 und 46,2 $\mathrm{g}$, im Alter von 4 Wochen 1036,5, 1154,5, 1115,3 und 1168,7 g, im Alter von 8 Wochen 1660,7, 1824,7, 1894,0 und 1744,2 $\mathrm{g}$ sowie im Alter von 12 Wochen 1816,0, 1999,0, 2044,0 und 1885,5 g. Die Schlachtausbeute belief sich bei den 12 Wochen alten Enten auf 71,5, 72,5, 73,7 und 71,3\%. Der Anteil des Brust- und Schenkelfleisches am Schlachtkörper lag bei 34,4, 34,1, 33,8 und 36,7 \%. Der Gehalt an Rohprotein im Brustfleisch betrug 20,2, 20,0, 20,3 und 20,7 \% und im Schenkelfleisch 20,1, 19,4, 18,8 und 19,4\%. Die entsprechenden Gehaltswerte für Rohfett lagen bei 10,3, 5,8, 8,3 und 14,9\% sowie bei 10,6, 6,4, 8,9 und 15,1\%. Der geringe Fettgehalt der lokalen Entenrassen macht sie für kommerzielle Kreuzungsprogramme interessant.

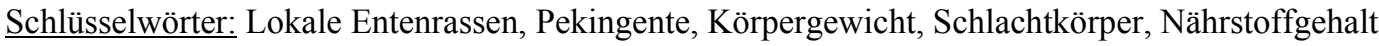

\section{Introduction}

In the last two decades there has been increasing popularity related to the conservation of local domestic animals in many countries. It is known that some breeds have already been lost and the others are found to be moving rapidly to the brink of extinction (HODGES, 1992). For this reason conservation actions have been started in most developed countries. On the other hand, although we have no statistical data on duck breeding potential in Turkey, it is only known that there are very few small-scale 
duck farms with rasing Pekin ducks (TESTIK,1995). In some regions of the country like Isparta local duck genotypes have been extensively raised for many years in small family farms. But, there is no information available on characteristics and performances of local duck breeds in Turkey (SELÇUK and AKYURT, 1986). Different organizations, such as FAO recognised the urgency of characterizing and conserving indigenous breeds in developing countries as soon as possible (HODGES, 1992).

There are also increasing demands in many countries for food produced by sustainable techniques (VARADI, 1995). ROMBOLI (1995) suggested that in order to increase the demand for duck meat, it is necessary to improve carcass composition and meat quality. The first objective in making duck meat more acceptable by the consumers is to increase the proportion of muscle, especially breast and leg muscles. So, we need information on different traits of the native ducks in Turkey.

The purpose of this research was to investigate growth, carcass traits and the nutrient content of meat of different local duck breeds in Isparta and in comparison with Turkish Pekins.

\section{Material and method}

The experiment was conducted with day old ducklings of three local ducks (Kara, Yesilbas and Boz) and Turkish Pekins. Each of the genotypes was one group with 30 ducklings. All groups were identified with wing number and placed in separate pens without sexing.

The birds were fed commercial starter ration (22\% protein and $3060 \mathrm{kcal} / \mathrm{kgME}$ ) for the first two weeks, and grower diet $(21 \%$ protein and $3200 \mathrm{kcal} / \mathrm{kgME})$ between 3 and 12 weeks of age (KOÇAK and YALÇIN, 1993). The birds hadn't have ad libitum.

Ducks were weighed weekly from hatch to 12 weeks of age. All living ducks were slaughtered at 12 weeks of age and were cut to determine the part of the carcasses. Three birds of each sex and each group were taken to analyse the chemical meat composition. Crude protein and fat analyses of meat were made by Kjeldahl and Soxhlet tool, respectively (JAMES, 1995; ANON, 1993). Bio-statistical analyses were done with MINITAB for WINDOWS (version 10.5). Mstatc was used for the test of significance.

Table 1

Average body weight of local duck genotypes and Turkish Pekins at different age (g) (Körpergewichte lokaler Entenrassen und Türkischer Pekingenten bei unterschiedlichem Alter)

\begin{tabular}{|c|c|c|c|c|c|c|c|c|c|}
\hline \multirow{2}{*}{$\begin{array}{l}\text { Age, } \\
\text { Weeks }\end{array}$} & \multirow[t]{2}{*}{ Sex } & \multicolumn{2}{|r|}{$\begin{array}{l}\text { Kara } \\
\bar{X} \pm S_{\bar{X}}\end{array}$} & \multicolumn{2}{|r|}{$\begin{array}{l}\text { Yesilbas } \\
\bar{X} \pm S_{\bar{X}}\end{array}$} & \multicolumn{2}{|r|}{$\begin{array}{l}\text { Boz } \\
\bar{X} \pm S_{\bar{X}}\end{array}$} & \multicolumn{2}{|r|}{$\begin{array}{l}\text { Turkish Pekin } \\
\bar{X} \pm S_{\bar{X}}\end{array}$} \\
\hline & & $\mathrm{n}$ & & $\mathrm{n}$ & & $\mathrm{n}$ & & $\mathrm{n}$ & \\
\hline \multirow[t]{2}{*}{0} & $\mathrm{M}$ & 12 & $42.80 \pm 0.89^{\text {cd }}$ & 12 & $44.20 \pm 1.38^{\mathrm{c}}$ & 8 & $48.60 \pm 0.60^{\mathrm{a}}$ & 10 & $46.80 \pm 0.74^{b}$ \\
\hline & $\mathrm{F}$ & 15 & $41.67 \pm 1.15^{\mathrm{d}}$ & 10 & $44.17 \pm 1.27^{\mathrm{c}}$ & 7 & $48.00 \pm 0.30^{\mathrm{a}}$ & 12 & $45.62 \pm 0.92^{\mathrm{b}}$ \\
\hline \multirow[t]{2}{*}{4} & $\mathrm{M}$ & 12 & $1099.0 \pm 19.2^{\mathrm{bc}}$ & 12 & $1198.8 \pm 33.6^{\mathrm{a}}$ & 8 & $1131.0 \pm 25.5^{\mathrm{abc}}$ & 10 & $1192.8 \pm 21.8^{\mathrm{a}}$ \\
\hline & $\mathrm{F}$ & 15 & $991.9 \pm 15.7^{\mathrm{d}}$ & 10 & $1070.0 \pm 36.4^{\mathrm{c}}$ & 7 & $1119.7 \pm 27.3^{\mathrm{abc}}$ & 12 & $1157.7 \pm 20.4^{\mathrm{ab}}$ \\
\hline \multirow[t]{2}{*}{8} & $\mathrm{M}$ & 12 & $1781.5 \pm 26.3^{b c}$ & 12 & $1996.3 \pm 53.7^{\mathrm{a}}$ & 8 & $2089.0 \pm 70.0^{\mathrm{a}}$ & 10 & $1865.9 \pm 55.4^{b}$ \\
\hline & $\mathrm{F}$ & 15 & $1534.3 \pm 21.7^{\mathrm{e}}$ & 10 & $1614.2 \pm 33.2^{\mathrm{de}}$ & 7 & $1732.3 \pm 9.2^{\mathrm{cd}}$ & 12 & $1648.0 \pm 32.3^{\mathrm{de}}$ \\
\hline \multirow[t]{2}{*}{12} & $\mathrm{M}$ & 12 & $1974.2 \pm 35.5^{\mathrm{b}}$ & 12 & $2244.0 \pm 54.7^{\mathrm{a}}$ & 8 & $2212.0 \pm 48.4^{\mathrm{a}}$ & 10 & $2007.0 \pm 32.4^{\mathrm{b}}$ \\
\hline & $\mathrm{F}$ & 15 & $1661.2 \pm 24.8^{\mathrm{e}}$ & 10 & $1709.0 \pm 41.5^{\mathrm{de}}$ & 7 & $1894.3 \pm 24.7^{\mathrm{bc}}$ & 12 & $1791.8 \pm 21.9^{\mathrm{cd}}$ \\
\hline
\end{tabular}

$\overline{\mathrm{a}, \mathrm{b}}=$ Different letters in the same row show significant difference $(\mathrm{P}<0.05)$. 


\section{Growth}

\section{Results and discussion}

Table 1 shows the means of the body weights up to the age of twelve weeks.

If we investigate the data for body weight we see that there are significant differences among genotypes and sexes. The average body weights of both sexes at the age of 8 weeks were 1660.7 to $1894.0 \mathrm{~g}$ and at the age of 12 weeks $1816.0-2044.0 \mathrm{~g}$. In this way, these values are lower to TESTIK et al. (1988), who has investigated Turkish Pekins with $2.35 \mathrm{~kg}$, but higher to small white ducks (KOCI et al., 1982) with $1.43 \mathrm{~kg}$ as well as to Shao ducks (HU and CHEN, 1988) and to Tsaiya ducks (HUANG et al., 1983) with 1.3 to $1.65 \mathrm{~kg}$. The Shao and Tsaiya ducks are specialized breeds for egg production. Male and females lines of commercial breeding programs with Pekin ducks for meat production have body weights at the age of 7-8 weeks of 3.6-4.0 kg and 2.6-3.0 kg, respectively (PINGEL, 2000).

Generally, the studies related to body weight of Pekin ducks in literatüre show a high variability between 2 and $4 \mathrm{~kg}$. But for the growth rate there is a good agreement.

The growth curves of males and females in the Figure demonstrate the characteristic growth rate for common ducks. In the first four weeks of life ducks have a very intensive growth rate. The highest daily gain of body weight is found at the age of 1820 days (WIEDERHOLD and PINGEL, 1997). At the age of 8 weeks ducks have reached almost $80 \%$ of the adult weight.

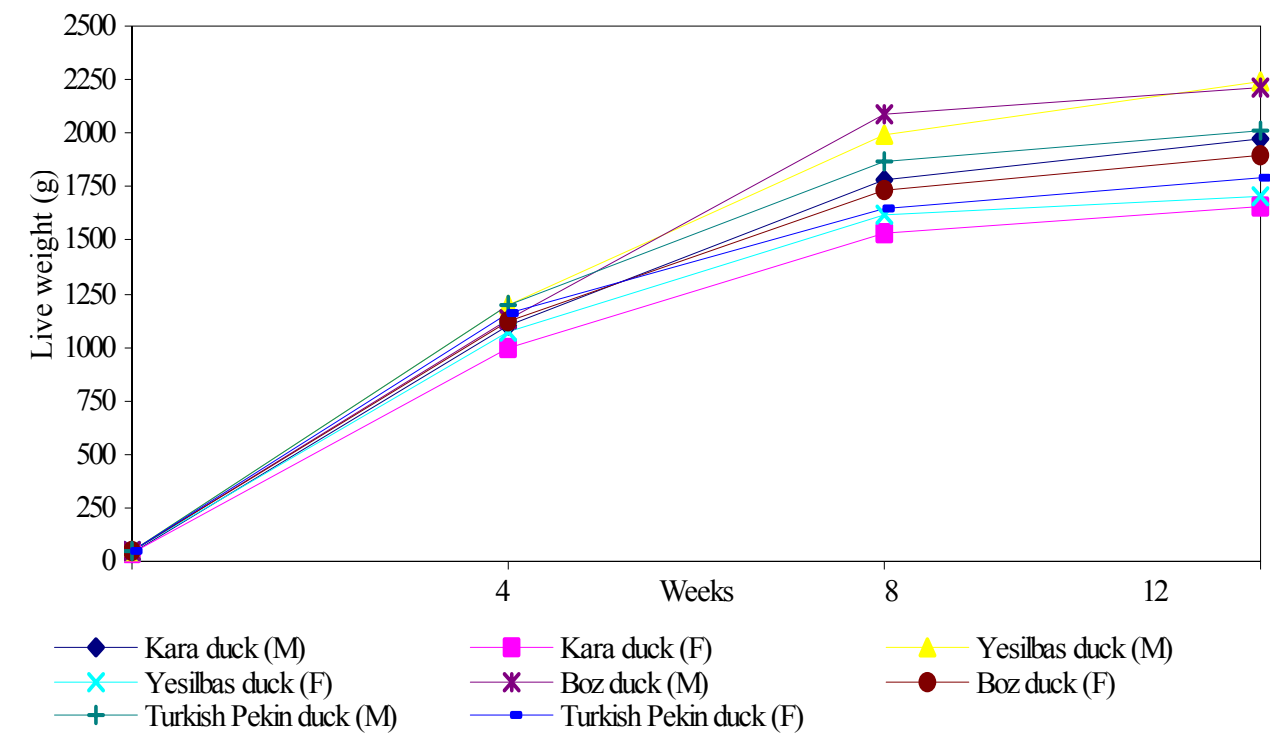

Figure: Growth curves of Local ducks and Turkish Pekins (Wachstumskurve untersuchter Entenrassen)

\section{Carcass traits}

At the age of 12 weeks the ducks have been slaughtered and cut. The means of the carcass characteristics are shown in Table 2.

In this study, Boz ducks had the highest relative carcass weight (incl. Edible organs) to body weight of live ducks. However, male Turkish Pekin ducks had the significant highest breast and leg percentages. Generally, the breast meat percentage is high in all genotypes. The reason is the relatively high age of 12 weeks. PINGEL (1990) has shown that the percentage of breast muscle in waterfowl is growing with increasing age. The growth rate of the body will be reduced, but the breast muscle tends to 
continue its intensive growth up to a greater age. Differences of percentages for heart and liver were not significant between genotypes, but there was a big difference for gizzard percentage between Kara and Boz ducks.

For the comparison of our data with literature, it has to be considered that sometimes the carcass includes the edible organs and sometimes not. KOÇAK and YALÇIN (1993) have found that the composition of carcass without edible organs was 28, 38 and $34 \%$ for bone, skin and meat yielrs, respectively. The percentages of carcass to body weight as well as the breast, wihg, thigh and drumsticks for males and females were $62.2-61.2,34.6-33.0,14.5-15.7,12.2-12.2$ and $9.5-10.2 \%$, respectively. In investigations of KSCHISCHAN et al. (1995) the carcass percentage of males and females was 62.4 and $63.44 \%$, respectively. The percentage of heart and liver with $0.7 \%$ and $2.9 \%$ was similar to our results.

Table 2

Composition of the body of different duck genotypes (\%) (Schlachtkörperzusammensetzung untersuchter Entenrassen)

\begin{tabular}{|c|c|c|c|c|c|c|c|c|c|}
\hline \multirow[t]{2}{*}{ Body parts } & \multirow[t]{2}{*}{$\begin{array}{l}\mathrm{S} \\
\mathrm{e} \\
\mathrm{x}\end{array}$} & \multicolumn{2}{|r|}{$\begin{array}{l}\text { Kara } \\
\bar{X} \pm S_{\bar{X}}\end{array}$} & \multicolumn{2}{|r|}{$\begin{array}{l}\text { Yesilbas } \\
\bar{X} \pm S_{\bar{X}}\end{array}$} & \multicolumn{2}{|r|}{$\begin{array}{l}\text { Boz } \\
\bar{X} \pm S_{\bar{X}}\end{array}$} & \multicolumn{2}{|r|}{$\begin{array}{l}\text { Turkish Pekin } \\
\bar{X} \pm S_{\bar{X}}\end{array}$} \\
\hline & & $\mathrm{n}$ & & $\mathrm{n}$ & & $\mathrm{n}$ & & $\mathrm{n}$ & \\
\hline \multirow[t]{2}{*}{ Carcass/body } & $\mathrm{M}$ & 6 & $70.06 \pm 1.09^{b}$ & 12 & $72.15 \pm 0.47^{\mathrm{ab}}$ & 8 & $73.85 \pm 0.88^{\mathrm{a}}$ & 10 & $71.48 \pm 0.69^{\mathrm{ab}}$ \\
\hline & $\mathrm{F}$ & 6 & $72.94 \pm 1.32^{\mathrm{ab}}$ & 8 & $73.07 \pm 1.75^{\mathrm{ab}}$ & 7 & $73.51 \pm 1.31^{\mathrm{a}}$ & 8 & $71.15 \pm 0.68^{\mathrm{ab}}$ \\
\hline \multirow[t]{2}{*}{ Breast/carcass } & $\mathrm{M}$ & 6 & $19.99 \pm 0.34^{\mathrm{b}}$ & 12 & $19.43 \pm 0.21^{\mathrm{bc}}$ & 8 & $19.98 \pm 0.78^{\mathrm{b}}$ & 10 & $21.89 \pm 0.47^{\mathrm{a}}$ \\
\hline & $\mathrm{F}$ & 6 & $17.20 \pm 0.39^{\mathrm{d}}$ & 8 & $18.13 \pm 0.57^{\text {cd }}$ & 7 & $18.07 \pm 0.36^{\mathrm{cd}}$ & 8 & $18.75 \pm 0.45^{\mathrm{bc}}$ \\
\hline \multirow[t]{2}{*}{ Legs/carcass } & $\mathrm{M}$ & 6 & $15.98 \pm 0.23^{\mathrm{ab}}$ & 12 & $15.50 \pm 0.11^{\mathrm{bc}}$ & 8 & $15.03 \pm 0.20^{\mathrm{cd}}$ & 10 & $16.75 \pm 0.29^{\mathrm{a}}$ \\
\hline & $\mathrm{F}$ & 6 & $15.67 \pm 0.04^{\mathrm{bc}}$ & 8 & $14.73 \pm 0.58^{\mathrm{de}}$ & 7 & $14.39 \pm 0.20^{\mathrm{e}}$ & 8 & $15.58 \pm 0.13^{b c}$ \\
\hline \multirow[t]{2}{*}{ Heart/carcass } & $\mathrm{M}$ & 6 & $1.09 \pm 0.07^{\mathrm{a}}$ & 12 & $1.09 \pm 0.04^{\mathrm{a}}$ & 8 & $0.96 \pm 0.06^{\mathrm{a}}$ & 10 & $1.08 \pm 0.04^{\mathrm{a}}$ \\
\hline & $\mathrm{F}$ & 6 & $0.95 \pm 0.00^{\mathrm{a}}$ & 8 & $1.10 \pm 0.06^{\mathrm{a}}$ & 7 & $1.07 \pm 0.07^{\mathrm{a}}$ & 8 & $1.02 \pm 0.05^{\mathrm{a}}$ \\
\hline \multirow[t]{2}{*}{ Liver/carcass } & $\mathrm{M}$ & 6 & $3.11 \pm 0.25^{\mathrm{ab}}$ & 12 & $3.03 \pm 0.15^{\mathrm{ab}}$ & 8 & $2.56 \pm 0.13^{\mathrm{cd}}$ & 10 & $2.62 \pm 0.06^{b c}$ \\
\hline & $\mathrm{F}$ & 6 & $2.22 \pm 0.09^{\mathrm{d}}$ & 8 & $2.80 \pm 0.16^{\mathrm{ab}}$ & 7 & $2.93 \pm 0.25^{\mathrm{ab}}$ & 8 & $3.20 \pm 0.22^{\mathrm{a}}$ \\
\hline \multirow[t]{2}{*}{ Gizzard/carcass } & $\mathrm{M}$ & 6 & $6.21 \pm 0.33^{\mathrm{a}}$ & 12 & $5.35 \pm 0.31^{b c}$ & 8 & $4.84 \pm 0.29^{c}$ & 10 & $5.48 \pm 0.13^{\mathrm{ab}}$ \\
\hline & $\mathrm{F}$ & 6 & $6.22 \pm 0.10^{\mathrm{a}}$ & 8 & $5.93 \pm 0.18^{\mathrm{ab}}$ & 7 & $4.84 \pm 0.14^{\mathrm{c}}$ & 8 & $5.05 \pm 0.24^{\mathrm{c}}$ \\
\hline \multirow[t]{2}{*}{ Intenstine/ body } & $\mathrm{M}$ & 6 & $4.55 \pm 0.21^{\mathrm{a}}$ & 12 & $4.14 \pm 0.16^{\mathrm{ab}}$ & 8 & $3.38 \pm 0.21^{\mathrm{c}}$ & 10 & $4.30 \pm 0.06^{\mathrm{ab}}$ \\
\hline & $\mathrm{F}$ & 6 & $4.42 \pm 0.01^{\mathrm{ab}}$ & 8 & $4.15 \pm 0.20^{\mathrm{ab}}$ & 7 & $3.91 \pm 0.22^{b}$ & 8 & $4.53 \pm 0.26^{\mathrm{a}}$ \\
\hline
\end{tabular}

$\overline{\mathrm{a}, \mathrm{b}}=$ Different letters in the same row show significant difference $(\mathrm{P}<0.05)$.

\section{Nutrient content of meat}

Means of protein and fat content of breast and leg meat are shown in Table 3.

Table 3

Meat quality of genotypes (\%) (Fleischqualität untersuchter Entenrassen)

\begin{tabular}{|c|c|c|c|c|c|c|}
\hline Quality traits & Sex & $\mathrm{n}$ & $\begin{array}{l}\text { Kara duck } \\
\bar{X} \pm S_{\bar{X}}\end{array}$ & $\begin{array}{l}\text { Yesilbas duck } \\
\bar{X} \pm S_{\bar{X}}\end{array}$ & $\begin{array}{l}\text { Boz duck } \\
\bar{X} \pm S_{\bar{X}}\end{array}$ & $\begin{array}{l}\text { Turkish Pekin duck } \\
\bar{X} \pm S_{\bar{X}}\end{array}$ \\
\hline \multicolumn{7}{|l|}{ Protein } \\
\hline \multirow[t]{2}{*}{ Breast } & $\mathrm{M}$ & 3 & $20.79 \pm 0.79^{\mathrm{a}}$ & $19.88 \pm 0.50^{\mathrm{ab}}$ & $20.68 \pm 0.16^{\mathrm{a}}$ & $20.76 \pm 0.20^{\mathrm{a}}$ \\
\hline & $\mathrm{F}$ & 3 & $19.70 \pm 1.23^{\mathrm{ab}}$ & $20.09 \pm 0.71^{\mathrm{ab}}$ & $19.97 \pm 0.23^{\mathrm{ab}}$ & $20.65 \pm 0.30^{\mathrm{a}}$ \\
\hline \multirow[t]{2}{*}{ Legs } & $\mathrm{M}$ & 3 & $20.45 \pm 0.65^{\mathrm{a}}$ & $19.33 \pm 0.27^{\mathrm{ab}}$ & $19.23 \pm 0.64^{\mathrm{ab}}$ & $19.48 \pm 0.38^{\mathrm{ab}}$ \\
\hline & $\mathrm{F}$ & 3 & $19.78 \pm 0.48^{\mathrm{ab}}$ & $19.41 \pm 0.37^{\mathrm{ab}}$ & $18.40 \pm 0.28^{\mathrm{b}}$ & $19.36 \pm 0.44^{\mathrm{ab}}$ \\
\hline \multicolumn{7}{|l|}{ Fat } \\
\hline \multirow[t]{2}{*}{ Breast } & $\mathrm{M}$ & 3 & $9.12 \pm 1.98^{b c}$ & $5.29 \pm 0.54^{\mathrm{h}}$ & $7.84 \pm 0.17^{\mathrm{de}}$ & $15.52 \pm 0.58^{\mathrm{a}}$ \\
\hline & $\mathrm{F}$ & 3 & $11.40 \pm 1.57^{\mathrm{b}}$ & $6.33 \pm 0.66^{\mathrm{fg}}$ & $8.81 \pm 0.38^{b c}$ & $14.35 \pm 1.10^{\mathrm{a}}$ \\
\hline \multirow[t]{2}{*}{ Legs } & $\mathrm{M}$ & 3 & $10.22 \pm 0.15^{\mathrm{bc}}$ & $5.87 \pm 1.24^{\mathrm{gh}}$ & $9.63 \pm 0.30^{b c}$ & $15.48 \pm 0.73^{\mathrm{a}}$ \\
\hline & $\mathrm{F}$ & 3 & $11.06 \pm 0.84^{\mathrm{bc}}$ & $6.90 \pm 0.99^{\mathrm{ef}}$ & $8.19 \pm 0.39^{\mathrm{cd}}$ & $14.80 \pm 0.67^{\mathrm{a}}$ \\
\hline
\end{tabular}

\footnotetext{
$\overline{\mathrm{a}, \mathrm{b}}=$ Different letters in the same row show significant difference $(\mathrm{P}<0.05)$.
} 
The percentage of protein in meat of ducks is around $20 \%$. The highest percentage of crude protein was observed for Turkish Pekins in breast and leg meat, and also for Kara duck leg meat.

The percentage of fat in breast and leg meat differed with genotypes. Turkish Pekin duck had a significant higher fat content in both breast and leg meat than the local breeds. Compared to the Yesilbas duck the fat content of Pekin ducks was more than twice higher. But also the other local duck breeds have significantly $(\mathrm{P}<0.05)$ produced meat with less fat in breast and leg compared with Turkish Pekin ducks. The local duck genotypes are suitable for meat production with lower fat content. They are more advantageous with their less fattened meat and should be used within commercial crossbred programs.

\footnotetext{
References

ANON:

Analyzis methods of food stuffs (book). The Ministry of Agriculture and Forest press, Ankara, Turkey, 1993
}

HODGES, J.:

The threat to in the geneous breeds in developing countries and options for action. Genetic conservation of domestic livestock. Vol.2: 47-55. CAB, International, 1992

HU, JP.; CHEN, L.:

Shao duck in China. CAP abstract 213, 114.rec. Poultry International, October, 148, 150, 1988

HUANG, H.H.; TAI, C.; TAI, JJL.; SHAW, JC.; PAN,CM.:

The breeding of White Tsaiya (Anas palatyrhynchos var.domestica) in Taiwan. CAP abstract 408,

JAMES, CS.: 128.rec. Free communication papers. 141-142; 3ref., 1983

KOCAK, C.; YALCIN, S.:

Duck Raising. Ege University press, İzmir/Turkey, 1993

KOCI, E.; BAUMGARTNER, J; ILLES, V.; PALANSKA, O.:

Carcass and nutritive value of the small white broiler duck and its crosses. CAP abstract 408, 64.rec. Archiv für Geflügelkunde 46 (1982) 4, 157-161; 5 ref., 1982

KSCHISCHAN, M.; WAGNER, A.; KNUST, U.; PINGEL, H.; KOHLER, D.:

Effect of different fattening methods on Mulards and Pekin ducks. Proc. of $10^{\text {th }}$ European Symposium on waterfowl, 62-65, 1995

PINGEL, H.:

Genetics of growth and meat production in waterfowl. In: R.D. CRAWFORD (ed.): Poultry Breeding ROMBOLI, I.: and Genetics. Elsevier, Amsterdam, 691-704, 1990

Production factors and meat quality in waterfowl. Proc. of $10^{\text {th }}$ European Symposium on waterfowl, 310-320, 1995

SELCUK, E.; AKYURT, I.:

Duck husbandry. Ministry of Agriculture and Forest press, N: 8, Ankara, Turkey, 1986

TESTIK, A.; PEKEL, E.; SARICA, M.:

An investigation on growth performance of Pekin duck. Çukurova University, Faculty of Agriculture, 3 (2), 1988

TESTIK, A.:

The Situation of ducks and geese production in Turkey. Proc. of $10^{\text {th }}$ European Symposium on

VARADI, L.: waterfowl, 43-45, 1995

Ecological aspest in integrated duck and fish production. Proc. of $10^{\text {th }}$ European Symposium on waterfowl, 8-19, 1995

WIEDERHOLD, S.; PINGEL, H.:

Growth of breast and leg muscles of waterfowl. Proc. $11^{\text {th }}$ European Symposium on waterfowl, Nantes, 541-548, 1997 
Received: 2002-01-10

Accepted: 2002-07-03

Authors' addresses

Dr. ERGUL IŞGUZAR

Süleyman Demirel University, Faculty of Agriculture, Depart. of Animal Breeding, Isparta-Turkey

Prof. Dr. CETIN KOCAK

Ege University, Faculty of Agriculture, Department of Animal Breeding, Izmir - Turkey

Prof. Dr. HEINZ PINGEL

Martin-Luther-University, Faculty of Agriculture, Department of Animal

Breeding and Husbandry with Veterinary Clinic

Adam-Kuckhoff-Strasse 35

D-06108 Halle (Saale)

Germany 